University of Nebraska - Lincoln

DigitalCommons@University of Nebraska - Lincoln

Nebraska Game and Parks Commission -- Staff

Research Publications

Nebraska Game and Parks Commission

November 1971

\title{
Survival of Some Freshwater Fishes in the Alkaline Eutrophic Waters of Nebraska
}

D. B. McCarraher

Nebraska Game and Parks Commission

Follow this and additional works at: https://digitalcommons.unl.edu/nebgamestaff

Part of the Environmental Sciences Commons

McCarraher, D. B., "Survival of Some Freshwater Fishes in the Alkaline Eutrophic Waters of Nebraska" (1971). Nebraska Game and Parks Commission -- Staff Research Publications. 24.

https://digitalcommons.unl.edu/nebgamestaff/24

This Article is brought to you for free and open access by the Nebraska Game and Parks Commission at DigitalCommons@University of Nebraska - Lincoln. It has been accepted for inclusion in Nebraska Game and Parks Commission -- Staff Research Publications by an authorized administrator of DigitalCommons@University of Nebraska - Lincoln. 


\section{Journal}

Vol. 28, No. 11, November 1971

\section{or the Fisheries Research}

\section{Board}

or Canada

Survival of Some Freshwater Fishes in the Alkaline Eutrophic

Waters of Nebraska

D. B. McCarraher 


\title{
Survival of Some Freshwater Fishes in the Alkaline Eutrophic Waters of Nebraska
}

\author{
D. B. MCCARRAHER \\ Nebraska Game and Parks Commission \\ Office of Limnology, Hastings College, Hastings, Nebraska 68901 USA
}

MCCARRAHER, D. B. 1971. Survival of some freshwater fishes in the alkaline eutrophic waters of Nebraska. J. Fish. Res. Bd. Canada 28: 1811-1814.

Of 14 species of freshwater fishes held in cages in one or more of 13 alkaline lakes and ponds in Nebraska, few species survived more than a month where carbonate alkalinity, mostly as compounds of $\mathrm{Na}_{2} \mathrm{CO}_{3}$ and $\mathrm{KCO}_{3}$, was above $300 \mathrm{mg} /$ liter. Of the 14 species tested, Sacramento perch (Archoplites interruptus), fathead minnow (Pimephales promelas), northern pike (Esox lucius), and the black bullhead (Ictalurus melas), were the most tolerant of alkaline environments. Most centrachid fishes except A. interruptus and the green sunfish (Lepomis cyanellus), did not survive more than a month in alkaline waters greater than $950 \mathrm{mg} / \mathrm{liter}$ total alkalinity. A lake classification index for slightly alkaline to strongly alkaline environments is presented, along with suggested fish species for introduction into such waters.

MCCARraher, D. B. 1971. Survival of some freshwater fishes in the alkaline eutrophic waters of Nebraska. J. Fish. Res. Bd. Canada 28: 1811-1814.

Sur un total de 14 espèces de poissons dulcaquicoles maintenus en cages dans un ou plusieurs de 13 lacs et étangs alcalins du Nebraska, peu d'espèces survécurent plus d'un mois là où les carbonates alcalins, surtout des composés de $\mathrm{Na}_{2} \mathrm{CO}_{3}$ et $\mathrm{KCO}_{3}$, dépassaient 300 $\mathrm{mg} /$ liter. Des 14 espèces soumises aux essais, la perche de Sacramento (Archoplites interruptus), le méné à grosse tête (Pimephales promelas), le grand brochet (Esox lucius), et la barbue noire (Ictalurus melas), se sont avérés les plus tolérants pour les milieux alcalins. La plupart des centrarchidés, sauf $A$. interruptus et le crapet vert (Lepomis cyanellus), n'ont pu vivre plus d'un mois dans des eaux d'alcalinité totale excédant $950 \mathrm{mg} /$ liter. On présente un index de classification des lacs, de légèrement à fortement alcalins, et on suggère les espèces à introduire dans chacun de ces milieux.

Received December 14, 1970

PAST investigations into the survival of freshwater fishes in the inland mineral waters of North America have been directed mainly toward the chloridesulfate type of habitat (Rawson and Moore 1944). This report on inland mineral lakes describes water quality characteristics of 13 lakes of various alkalinities scattered throughout the $52,000 \mathrm{~km}^{2}$ sandhill region of Nebraska. Field investigations were conducted from 1960 to 1967 to determine the survival of 14 fish species in one or more of the 13 lakes. Based partially on these experimental results, a list of fish species is suggested for introduction into slightly alkaline to strongly alkaline environments.

The ecological relation between alkalinity and northern pike (Esox lucius), fathead minnow (Pimephales promelas), and the Sacramento perch (Archoplites interruptus), along with a general limnological assessment of these lakes was described earlier

Printed in Canada (J1993)
(McCarraher unpublished data 1962; McCarraher and Thomas 1968; McCarraher and Gregory 1970).

Methods and materials - Some of the experimental fish (Micropterus salmoides, $M$. dolomieui, Ambloplites rupestris, Ictalurus punctatus, Morone americana, $M$. chrysops, and Pomoxis nigromaculatus) were taken from hatchery stock and selected for robustness and freedom from external parasites. The remaining species $(E$. lucius, Stizostedion vitreum vitreum, Cyprinus carpio, Lepomis cyanellus, Perca flavescens, Ictalurus melas, A. interruptus, and Aplodinotus grunniens) were captured by seines and frame nets from freshwater lakes. All species were either age I or II and were chemicallythermally tempered to lake water for $2-4 \mathrm{hr}$.

The fish, except those of two species, were then released into $1.1-\mathrm{m}^{3}$ cages constructed of $8-\mathrm{mm}$ mesh galvanized wire, and the cages anchored near shore in about $0.5-1 \mathrm{~m}$ depth. The cages were examined each hour for the first 6 $\mathrm{hr}$ and dead or distressed fish removed. If the fish survived the initial 48-hr period, the cages were then checked every 2-3 days. That mortality of the experimental fish was due to starvation rather than the direct influence of alkaline 
TABLE 1. Survival of some freshwater fishes and related water chemistry, in milligrams per liter, in Nebraska lakes of various alkalinities.

\begin{tabular}{|c|c|c|c|c|c|c|c|c|c|c|c|}
\hline Lake & $\begin{array}{l}\text { Survival } \\
\text { time }^{\mathrm{a}}\end{array}$ & $\begin{array}{l}\text { Total } \\
\text { alkalinity } \\
\text { range }\end{array}$ & $\begin{array}{c}\text { Average } \\
\mathrm{CO}_{3} \\
\text { alkalinity }\end{array}$ & $\begin{array}{l}\text { Total } \\
\text { dissolved } \\
\text { solids }\end{array}$ & $p \mathrm{H}$ & $\mathrm{Cl}$ & $\mathrm{SO}_{4}$ & $\mathbf{K}$ & $\mathrm{Na}$ & $\mathrm{Ca}$ & $\begin{array}{c}\text { Total } \\
\text { hardness }\end{array}$ \\
\hline \multicolumn{12}{|c|}{ Northern pike } \\
\hline Big Alkali & Indefinite & $460-950$ & 130 & 1120 & 9.3 & 20 & 14 & 90 & 210 & 38.0 & 50 \\
\hline Smithys Pond \#1 & $36-48 \mathrm{~h}$ & $886-880$ & 254 & 9230 & 10.5 & 235 & 600 & - & 4200 & 50.0 & 12 \\
\hline Hudson & $12-14 \mathrm{~m}$ & $820-1250$ & 290 & 1170 & 9.5 & 30 & 30 & 300 & 350 & 20.0 & 200 \\
\hline Smithys L. & $50-58 \mathrm{~h}$ & $2035-2050$ & 769 & 3449 & 9.8 & 140 & 120 & 1800 & 1600 & 35.0 & 120 \\
\hline Smithys Pond \#2 & $6-8 \mathrm{~h}$ & $3936-3940$ & 960 & 11600 & 10.8 & 300 & 860 & - & 3200 & 0.0 & 140 \\
\hline Little Alkali & $6-12 \mathrm{~h}$ & $4500-4508$ & 1139 & 6250 & 10.3 & 350 & 344 & - & 1184 & 4.0 & 10 \\
\hline \multicolumn{12}{|c|}{ Walleye } \\
\hline Big Alkali & $2-4 y$ & $300-980$ & 85 & 860 & 9.3 & 17 & 12 & 80 & 120 & 30.0 & 42 \\
\hline Smithys L. & $10-18 \mathrm{~h}$ & $1890-1895$ & 714 & 2315 & 9.6 & 160 & 40 & 750 & 1000 & 48.8 & 114 \\
\hline McKeel Pond \#2 & $28-30 \mathrm{~d}$ & $1921-2060$ & 680 & 2980 & 9.4 & 140 & 40 & 1200 & 1100 & 59.0 & 152 \\
\hline Little Alkali & $4-10 \mathrm{~h}$ & $2810-2810$ & 940 & 2130 & 9.7 & - & - & 660 & 720 & - & 20 \\
\hline \multicolumn{12}{|c|}{ Black bullhead } \\
\hline Walgren & Indefinite & $380-700$ & 110 & 380 & 8.5 & 8 & 4 & 4 & 18 & 102.0 & 329 \\
\hline Smithys L. & $30-33 d$ & $1802-2160$ & 620 & 2050 & 9.5 & 80 & 38 & 700 & 800 & 50.0 & 130 \\
\hline Smithys Pond \#1 & $18-22 \mathrm{~h}$ & $3280-3300$ & 1802 & 4320 & 9.9 & 50 & 160 & 900 & 1800 & 4.0 & 20 \\
\hline \multicolumn{12}{|c|}{ Channel catfish } \\
\hline Smithys L. & $10-18 \mathrm{~h}$ & $1890-1895$ & 714 & 2315 & 9.6 & 160 & 40 & 750 & 1000 & 48.0 & 114 \\
\hline & & & & White perch & & & & & & & \\
\hline Walgrenb & Indefinite & $380-700$ & 110 & 380 & 8.5 & 8 & 4 & 4 & 18 & 102.0 & 329 \\
\hline Rogers & $6-8 d$ & $1700-1780$ & 578 & 1980 & 9.3 & 34 & 14 & 215 & 300 & 20.0 & 768 \\
\hline Smithys L. & $18-20 \mathrm{~h}$ & $2176-2180$ & 918 & 2860 & 9.8 & 90 & 50 & 1200 & 1600 & 30.0 & 115 \\
\hline Smithys Pond \#1 & $12-14 \mathrm{~h}$ & $3280-3215$ & 1800 & 4300 & 9.9 & 50 & 160 & 910 & 1800 & 10.0 & 20 \\
\hline \multicolumn{12}{|c|}{ White bass } \\
\hline Little Alkali & $4-10 \mathrm{~h}$ & $2810-2810$ & 940 & 2130 & 9.7 & - & - & 660 & 720 & - & 20 \\
\hline Smithys Pond \#1 & $6-9 h$ & $3706-3715$ & 2256 & 5100 & 9.8 & 68 & 190 & 1900 & 2200 & 4.0 & 14 \\
\hline Smithys L. & $10-18 \mathrm{~h}$ & $1890-1895$ & 714 & $\begin{array}{l}\text { Drum } \\
2315\end{array}$ & 9.6 & 160 & 40 & 750 & 1000 & 48.0 & 114 \\
\hline \multicolumn{12}{|c|}{ Largemouth bass \& bluegill } \\
\hline Big Alkali & Indefinite & $300-950$ & 85 & 860 & 9.3 & 17 & 12 & 80 & 120 & 30.0 & 42 \\
\hline Stout & $3-4 m$ & $270-420$ & 145 & 500 & 9.5 & 99 & 38 & 92 & 80 & 56.0 & 119 \\
\hline McKeel Pond \#1 & $10-11 \mathrm{~d}$ & $1143-1250$ & 442 & 1275 & 9.3 & 100 & 60 & 250 & 450 & 40.0 & 2118 \\
\hline \multicolumn{12}{|c|}{ Rock bass } \\
\hline McKeel Pond \#5 & $12 \mathrm{~d}$ & $1360-1410$ & 272 & 1410 & 9.5 & 80 & 44 & 200 & 350 & 52.0 & 80 \\
\hline McKeel Pond \#2 & $28-30 \mathrm{~d}$ & $1921-2060$ & 680 & 2980 & 9.4 & 140 & 40 & 1200 & 1100 & 59.0 & 152 \\
\hline \multicolumn{12}{|c|}{ Sacramento perch } \\
\hline Walgren & Indefinite & $380-700$ & 110 & 380 & 8.5 & 8 & 4 & 4 & 18 & 102.0 & 329 \\
\hline White & $12-18 \mathrm{~m}$ & $1100-2100$ & 466 & 1880 & 9.1 & 29 & 620 & 187 & 435 & 33.0 & 48 \\
\hline Smithys L. & $96-98 \mathrm{~d}$ & $1906-3060$ & 816 & 2223 & 9.5 & 170 & 38 & 800 & 1200 & 50.0 & 120 \\
\hline Little Alkali & $22-24 d$ & $2040-2870$ & 1026 & 2850 & 9.7 & 100 & 120 & 775 & 740 & 17.0 & 35 \\
\hline \multicolumn{12}{|c|}{ Smallmouth bass } \\
\hline Little Alkali & $4-10 \mathrm{~h}$ & $2810-2810$ & 940 & 2130 & 9.7 & - & - & 660 & 720 & - & 20 \\
\hline East Twin & $6-12 m$ & $1430-2960$ & 530 & $\begin{array}{c}\text { Green sunfis } \\
2830\end{array}$ & $h_{9.5}$ & 100 & 43 & 500 & 655 & 22.0 & 100 \\
\hline \multicolumn{12}{|c|}{ Fathead minnow } \\
\hline White & $12-18 \mathrm{~m}$ & $1100-2100$ & 466 & 1880 & 9.1 & 29 & 620 & 187 & 435 & 33.0 & 48 \\
\hline
\end{tabular}

${ }^{a} h$, hours; d, days; m, months; y, years.

bWestern distribution limit in North America. 
compounds was unlikely, as food organisms were found in the stomachs of dead fish. Pimephales promelas and $S$. vitreum vitreum were not confined to cages but were released directly into Big Alkali and Smithys lakes. These releases were examined periodically with gilland frame nets.

Dissolved oxygen concentrations remained at 5.8 $\mathrm{mg} / \mathrm{liter}$ or above throughout the tests. Water quality was determined by standard methods (American Public Health Association 1965). Alkalinity and $p \mathrm{H}$ values were determined immediately following the collection of water samples from lake and pond sites shown in Table 1.

Results and discussion - Of the 14 species tested, those with the most noteworthy tolerance to alkalinity were the Sacramento perch and the fathead minnow; they survived 12-18 months in lakes where the total alkalinity ranged from 1000 to $2000 \mathrm{mg} /$ liter. The green sunfish, the next most tolerant species to medium alkaline waters, occurs naturally in several sandhill lakes where the maximum seasonal alkalinity does not exceed $2000 \mathrm{mg} / \mathrm{liter}$ (e.g., East Twin Lake, Table 1). The species has survived and reproduced in Skull Lake, where the alkalinity fluctuates between 400 and $960 \mathrm{mg} /$ liter (McCarraher and Thomas 1968).

Northern pike survived for about 14 months in the medium alkaline waters of Hudson Lake until the total alkalinity exceeded $1200 \mathrm{mg} /$ liter and the carbonate alkalinity exceeded $600 \mathrm{mg} /$ liter (Table 1). In Big Alkali Lake, a pike population has survived since the early 1950 's, the success of annual recruitment depending upon the alkalinity concentration of the water during the spawning season; alkalinity values in excess of $950 \mathrm{mg} /$ liter normally cause extensive mortality of eggs and fry (unpublished data).

The black bullhead, Ictalurus melas, and the channel catfish, I. punctatus, revealed noteworthy differences in ability to survive. Ictalurus melas

TABLE 2. Some suggested fish species for introduction into alkaline eutrophic lakes of the world.

\begin{tabular}{|c|c|c|c|c|}
\hline Lake typea & $\begin{array}{l}\text { Total } \\
\text { alk. range }\end{array}$ & $\begin{array}{l}\text { Carbonate } \\
\text { alk. range }\end{array}$ & $\underset{\text { range }}{\mathrm{K}}+\mathrm{Na}$ & Species \\
\hline Slightly alkaline & $<900$ & $<250$ & $<200$ & $\begin{array}{l}\text { Ambloplites rupestris } \\
\text { Aplodinotus grunniens } \\
\text { Ictalurus punctatus } \\
\text { Lepomis macrochirus } \\
\text { Micropterus dolomieui } \\
\text { Micropterus salmoides } \\
\text { Morone americana } \\
\text { Pomoxis nigromaculatus }\end{array}$ \\
\hline Moderately alkaline & $1200-1800$ & $550-850$ & $350-400$ & $\begin{array}{l}\text { Cyprinus carpio } \\
\text { Esox lucius } \\
\text { Ictalurus melas } \\
\text { Lepomis cyanellus } \\
\text { Morone chrysops } \\
\text { Perca flavescens } \\
\text { Stizostedion vitreum vitreum } \\
\text { Archoplites interruptus }\end{array}$ \\
\hline & & & & $\begin{array}{l}\text { Clupeonella abrau }{ }^{\mathrm{b}} \\
\text { Fundulus kansae } \\
\text { Pimephales promelas } \\
\text { Tilapia aureab }\end{array}$ \\
\hline Strongly alkaline & $1800-3000+$ & $900-1200+$ & $400-2000+$ & $\begin{array}{l}\text { Craterocephales fuviatilis } \mathrm{b} \\
\text { Culaea inconstans } \\
\text { Cyprinodon variegatus } \\
\text { Fundulus majalis } \\
\text { Mugil cephalus } \\
\text { Tilapia galilaea } \\
\text { Tilapia aureab }\end{array}$ \\
\hline
\end{tabular}

aRefers to the author's classification of alkaline waters based on his examination of about 1200 lakes in North America and Africa.

bSpecies not presently found in North American alkaline waters but may have potential for successful adaptation. 
survived for a considerably longer period than $I$. punctatus in the strongly alkaline water of Smithys Lake.

The walleye, $S$. vitreum vitreum, survived up to 4 years in Big Alkali Lake, where carbonate alkalinity seldom exceeded a range between 60 and 90 $\mathrm{mg} /$ liter. Fingerling and adult fish can survive in Big Alkali Lake; however, natural reproduction was greatly curtailed when carbonate alkalinity values exceeded $90 \mathrm{mg} / \mathrm{liter}$ during spawning season (unpublished data). Early aquaria studies by Young (1923) using various concentrations of alkaline compounds indicated that walleye could not survive with carbonate alkalinity concentrations greater than $72 \mathrm{mg} / \mathrm{liter}$, whereas Rawson and Moore (1944) reported that the species survived in saline lakes of Saskatchewan where the total alkalinity was about $483 \mathrm{mg} / \mathrm{liter}$. The salts of these saline lakes are for the most part sulfates of sodium and magnesium and therefore chemically different from those of Nebraska lakes.

Channel catfish (I. punctatus), bluegill (Lepomis macrochirus), largemouth bass (Micropterus salmoides), smallmouth bass (Micropterus dolomieui), and rock bass ( $A$. rupestris), were found to be unsuitable for medium to strongly alkaline waters and are suitable only for introduction into waters classified as slightly alkaline (Table 2). Aquaria experiments with alkaline water by Young (1923), Calabrese (1969), and Stiemke and Eckenfelder (1947) all indicated that the death point for $L$. macrochirus in a $\mathrm{Na}_{2} \mathrm{CO}_{3}$ solution was $120-160$ $\mathrm{mg} /$ liter. Observations by the author (unpublished data for 1954-1965) showed that survival of $L$. macrochirus and $M$. salmoides in Big Alkali Lake depended on the carbonate alkalinity remaining below $250 \mathrm{mg} /$ liter for periods greater than 3 months of the year. By contrast, Renfro (1959) has described significant survival of $M$. salmoides in noncarbonate chlorosulfate waters below 9\% total dissolved solids with progressive lethal effects between 9 and $15 \%$.

Sacramento perch not only appeared to have superior survival qualities for alkaline waters but is presently found living in several of the noncarbonate saline lakes of North Dakota, Colorado, and Nevada (McCarraher and Gregory 1970).
The fathead minnow inhabits numerous alkalinesaline lakes throughout the northern Great Plains (Nebraska, South Dakota, North Dakota, and the prairies of southern Saskatchewan and Manitoba) (McCarraher and Thomas 1968). The green sunfish, together with the Sacramento perch and the fathead minnow, are the most adaptable of Nebraska's fish fauna for survival in alkaline waters.

A list of species for intorduction into alkaline waters (Table 2) is suggested on the basis of experiments in Nebraska lakes; other species, not tested, are included for consideration.

Acknowledgments - The advice and editorial assistance of Mr R. E. Thomas and the encouragement of Mr G. Foster during the course of this study is gratefully acknowledged.

American Public Health Association. 1965. Standard methods for the examination of water and wastewater. 12th ed. American Public Health Association, New York, N.Y. 769 p.

Calabrese, A. 1969. Effect of acids and alkalies on survival of bluegills and largemouth bass. U.S. Bur. Sport Fish. Wildl. Tech. Pap. 42: 10 p.

MCCarraher, D. B. 1962. Northern pike, Esox lucius, in alkaline lakes of Nebraska. Trans. Amer. Fish. Soc. 91: 326-329.

1970. Some ecological relations of fairy shrimp in alkaline habitats of Nebraska. Amer. Midland Natur. 84: 59-68.

McCarraher, D. B., AND R. W. Gregory. 1970. The current status and distribution of Sacramento perch, Archoplites interruptus, in North America. Trans. Amer. Fish. Soc. 99: 700-707.

MCCARRAHER, D. B., AND R. E. Thomas. 1968. Some ecological observations on the fathead minnow, Pimephales promelas, in the alkaline waters of $\mathrm{Ne}$ braska. Trans. Amer. Fish. Soc. 97: 52-55.

Rawson, D. S., and J. E. Moore. 1944. The saline lakes of Saskatchewan. Can. J. Res. 22: 141-201, RENFRO, W. C. 1959. Survival and migration of freshwater fishes in salt water. Tex. J. Sci. 11: 172180.

Stiemke, R. E., AND W. W. ECKenfelder. 1947. A practical method for predicting the effects of common acids and alkalies on the survival of fish. Dep. Eng. Res. Bull. North Carolina State Coll. 33: 45 p.

YounG, R. T. 1923. Resistance of fish to salt and alkalinity. Amer. J. Physiol. 65: 373-388. 